\title{
ADD3/NUP98 Fusion Gene
}

National Cancer Institute

\section{Source}

National Cancer Institute. ADD3/NUP98 Fusion Gene. NCI Thesaurus. Code C99679.

A fusion gene that results from a chromosomal translocation $t(10 ; 11)(q 25 ; p 15)$ which

fuses the 5 ' half of the ADD3 gene with the 3' half of the NUP98 gene. This

rearrangement is associated with T-cell acute lymphoblastic leukemia. 